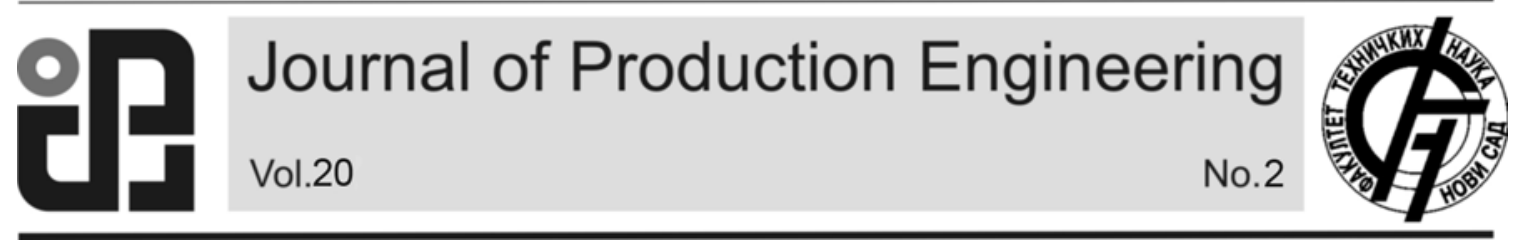

JPE (2017) Vol.20 (2)

Adekomaya, O., Jamiru, T., Sadiku, R., Huan, Z., Oboirien, B.

Preliminary Note

\title{
EXPLORING THE THERMAL PROPERTIES OF FLY ASHED-BASED GEOPOLYMER MATERIALS FOR COOLING APPLICATION IN BUILDINGS
}

Received: 11 July 2017 / Accepted: 08 September 2017

Abstract: Fly ash materials are the by-products of coal combustion process and the volume of this waste alone, accounts for about $80 \%$ of the total waste volume from a coal power plant. Part of the reclamation strategy of fly ash material is highly noticeable in the additives for cement production and this approach has recorded significant progress in view of its negative impact on the environment and also the process is generally cleaner due to the significantly low $\mathrm{CO}_{2}$ emission. In light of the above, a comprehensive and detailed study is therefore needed to explore some of inherent properties of fly ash material for passive cooling in buildings and its adjoining area. Energy consumption in buildings is projected to account for $\sim 50 \%$ of world energy demand by 2050 and the underlying point of this research is to $x$-ray the low thermal conductivity of fly ash geopolymer materials for possible application in passive cooling of buildings and the conclusion drawn from this work may be explored by researchers for further study.

Key words: Passive cooling; Building; Fly-ash geopolymer; Phase change materials; environmental waste

Isključivanje termalnih osobina materijala geopolimera na osnovu letala za hlađenje u zgradi. Materijali letećeg pepela su nusproizvodi procesa sagorevanja uglja i volumen tog otpada samo, čini oko 80\% ukupnog zapreminog otpada iz termoelektrane. Deo strategije reklamiranja materijala za pepeo je vrlo izražen u aditivima za proizvodnju cementa i ovaj pristup je zabeležio značajan napredak s obzirom na negativan uticaj na životnu sredinu, a i proces je generalno čistiji zbog značajno niskih emisija $\mathrm{CO}_{2}$. U svetlu gore navedenog, stoga je potrebna sveobuhvatna i detaljna studija kako bi se istražile neke od inerentnih svojstava materijala za pepeo koji se pali za pasivno hlađenje u zgradama i njegovoj susednoj oblasti. Projekcija potrošnje energije u zgradama će iznositi $\sim 50 \%$ svetske potražnje energije do 2050. godine, a osnovna tačka ovog istraživanja je rentgensko ispitivanje niske toplotne provodljivosti geopolimerskih materijala za pepeo za moguću primenu u pasivnom hlađenju zgrada i zaključak iz ovog pregleda rada istraživači mogu koristiti za dalja istraživanja.

Ključne reči: Pasivno hlađenje; Building; Geopolimera sa pepelom; Materijali za promenu faze; ekološki otpad

\section{INTRODUCTION AND BACKGROUND STUDY}

Coal-fired power plant has remained one of the largest sources of energy worldwide, accounting for about $36 \%$ of the world electricity generation and this dominance is likely to remain until the next decade [1]. Many literatures [2, 3] have affirmed that a large volume of fly and bottom ash wastes are generated from coal-fired power plants, in which many these authors described as not environmentally-friendly. Conventionally, these ashes are normally dumped for landfilling or probably used for construction. Recent studies [3, 4] showed that fly ash accounted for between $80-90 \%$ of total by-product produced from coal-fired plant, while only between $10-20 \%$ volume of bottom ash was generated from the same process. In view of the quantity of fly ash generated, this research study was undertaken in an attempt to further reduce its environmental impact by exploring wider applications of this waste. Figure 1(a) and (b) shows the volume of fly ash waste generated in the USA from 2008 to 2013 and its corresponding area of application. As evidenced in Fig. 1(a), the volume of unutilized fly ash appeared not to have shown considerable decline between 2008 and 2013, while the application of fly ash geopolymer material seems to have gained significant success as additives in Portland cement manufacturing and other materials for construction. Part of the reasons advanced by the construction and building industries are based on the high thermal insulation properties offered by geopolymer materials, which has increased its patronage for construction purposes (Fig.1b). According to Zhang, et al. [5], fly ash geopolymer materials are known for their low thermal conductivities, which may offer good thermal insulation thereby resulting in sustainable binders for most engineering works.

Recent findings in building system, have shown that energy demand in this sector accounts for $\sim 41 \%$ of global energy consumption [6] and it is predicted that this demand will rise to $\sim 50 \%$ by the year 2050 going by the surge in demands for heating and air conditioning of residential houses, mostly in urban cities. Many authors [7, 8] have reported a lot of progress made in the application of PCM in preserving energy in buildings, but a lot of difficulties have also been attributed to PCMs and most importantly in its practical application. Key of the drawback in the application of PCMs is its high flammability which makes it difficult for them to be exposed to high temperature. This is evident in the numerous papers 
(Fig.2) published in recent years as most of the experimental findings in these literatures failed to address this practical application of phase change materials in building. Another disadvantage reported by Konuklu, et al. [9] showed that PCMs sometimes proof difficult to hold in the matrix most especially at liquid state as some PCMs (mostly organic ones) evaporate and sometimes release part of their organic compound.
Salt hydrates are typical example in view of their water content. According to Akeiber, et al. [10], PCMs shows some shortcoming that may limit their application in practise. These include high volume variation during transition state and low thermal conductivity which poise a great challenge to be used in passive cooling system.
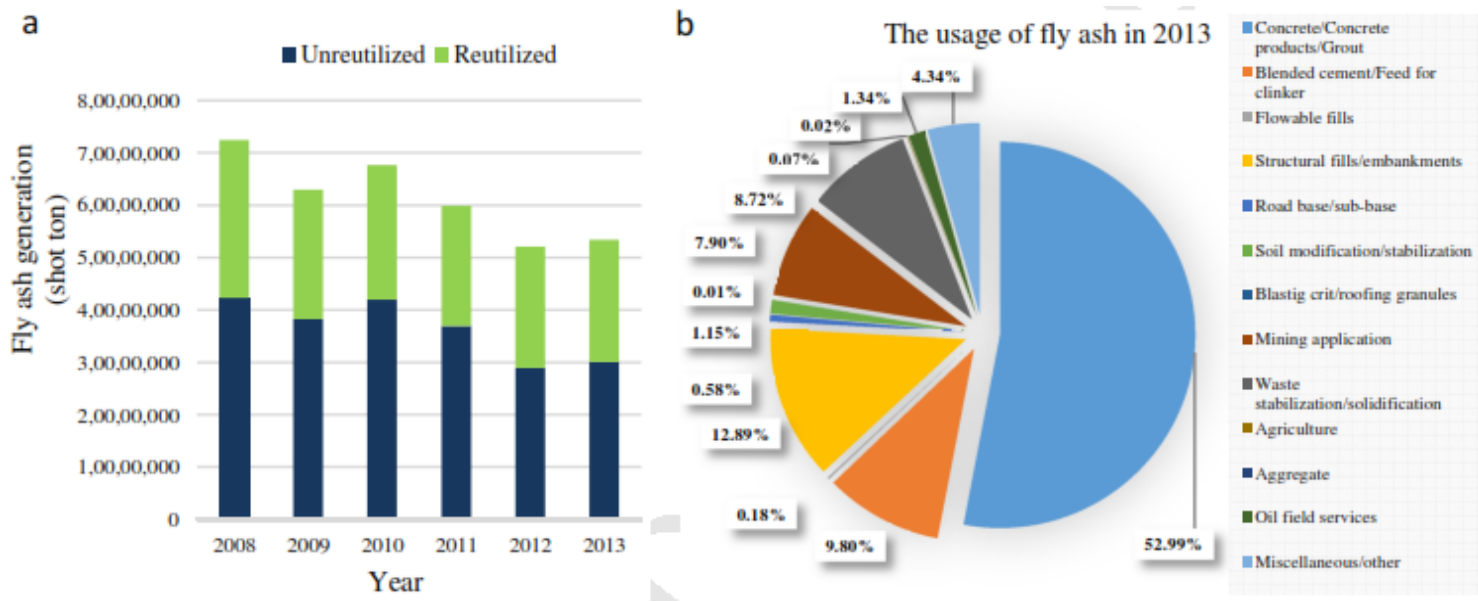

Fig.1. (a) The volume of fly ash generated in the USA between 2008-2013. (b) Applicable area of fly ash geopolymer materials as at 2013. (Adapted from Zhuang et al., 2016)

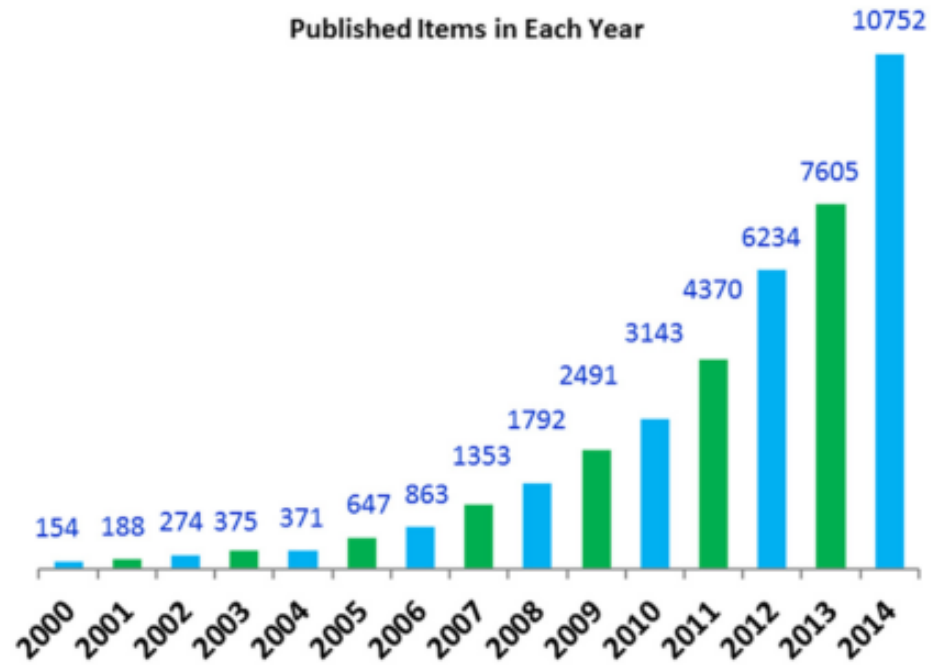

Fig. 2. Available papers published on PCMs from 2000 to 2014. Adapted from Akeiber, et al. [10]

These shortcoming may have informed this study, with the hope of exploring alternative materials with reasonable thermal conductivity for energy conservation in buildings. In order to further justify the relevance of fly-ash geopolymer materials for cooling applications, the research conducted by ul Haq, et al. [11] benchmarked the thermal conductivity values for fly-ash geopolymer materials to be $\sim 0.58 \mathrm{~W} / \mathrm{mK}$ when compared to bottom ash geopolymer, which is $\sim 0.85$ $\mathrm{W} / \mathrm{mK}$. In view of the fact that low thermal conductivity materials are currently being studied for sustainable energy saving [12], this thermal conductivity property of fly-ash geopolymer materials will be explored in this study for possible application in buildings. Although, the density of a typical geopolymer material is considerably high, as reported in past works [13, 14], this physical property may not necessarily be an inhibiting factor, as this strength may be advantageous in reinforcement purposes.

\section{SUSTAINABILITY OF PHASE CHANGE MATERIALS (PCMS) IN COOLING APPLICATION}

Cooling in building is primarily achieved by using existing pavement improvement either with the introduction of PCMs or novel designs or by introducing new materials to existing pavements [15]. The daily peak of surface temperature of a pavement has been a subject of research in recent times and most of the established conclusion in many literatures 
consider this suface temperature as a function of air temperature, solar irradiation and latitude of the building. Correspondingly, the daily peak surface temperature is being minimized by three approaches as shown in table 1 and geopolymer materials could be helpful to reduce the rate of the absorption and also raise the thermal inertia of the building. The prospect of geopolymer materials to enchance the existing cooling methods as predicted in Table 1 is borne out of some of the reported additives geopolymer materials have functioned satisfactorily and one of such application is the binders for concrete production.

\section{Existing cooling method}

Absorption

Evaporation

Storage

\section{Prediction with incorporation of geopolymer} materials into the existing cooling mathod

Table 1: Summary of cooling in building and the projection of geopolymer enchancement

Key of the property of phase change materials (PCMs) that have been extensively relied upon in building is their latent heat thermal energy and this property has received a lot of interest in many industries [16]. The concept of energy storage in PCMs is still the most widely used technology, in view of its large energy storage capacity, which presents an isothermal behaviour during the evaporative cooling in building. Although, this approach is seen to have minimized the peak heating and cooling loads with the prospect of keeping the indoor temperature at considerable level, thereby reducing the overall thermal load occasioned by house equipment. The key advantage of PCMs, as reported in literatures, revolves around their storage potential, with reasonable change in the configuration of building designs. Based on the aforementioned conclusion, some researchers [17-19] have expressed divergent views on the sustainability of PCMs in cooling application, as a result of the sudden rise in temperature during summer period, as the temperature rise may hinder complete solidification of PCMs at night, thereby reducing their performance during day. In an extensive literature reviews conducted by Souayfane, et al. [6], these authors affirmed that the astronomical increase in global population coupled with increasing energy demand, may further deepen the deficit in energy demand in the housing sector, thereby worsening global energy shortfall. According to a report released by the International Energy Agency (IEA), the primary energy production has increased from $30 \%$ to $49 \%$ in the last 20 years, while the $\mathrm{CO}_{2}$ emissions have equally increased by $43 \%$ under the same influence. This may further heighten the cooling demand in locations where urbanization is fast growing, as shown in Fig. 2.

In a similar study developed by IEA in 2010, this agency predicted that the space cooling in buildings in European states alone may reached $220 \mathrm{TWh}$ and it was further reported that an additional increases of about $+38 \%$ in 2020 and $+72 \%$ in 2030 are foreseen. In addition, the survey released by European Technology Platform on Renewable Heating and Cooling (RHC) equally collaborated previous report that the cooling demand in the EU and by extension, the world are predicted to rise most importantly in residential sectors, as illustrated in Figure 3.

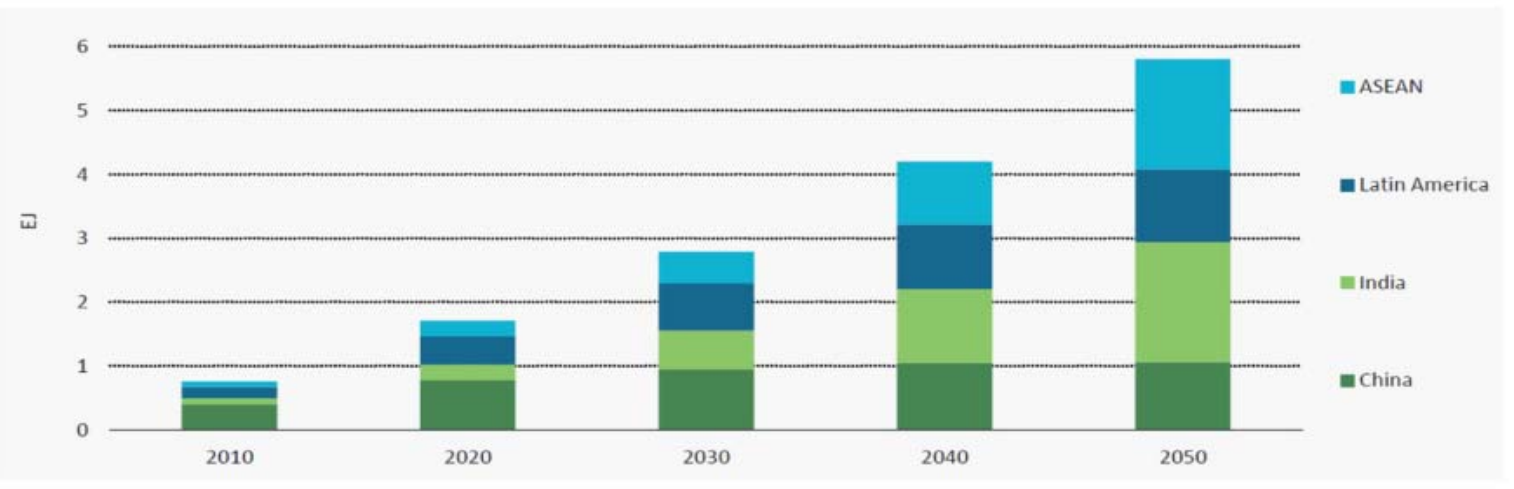

Fig. 3. Prediction of cooling demand in highly populated region of the world. Adapted from Souayfane, et al. [6] 


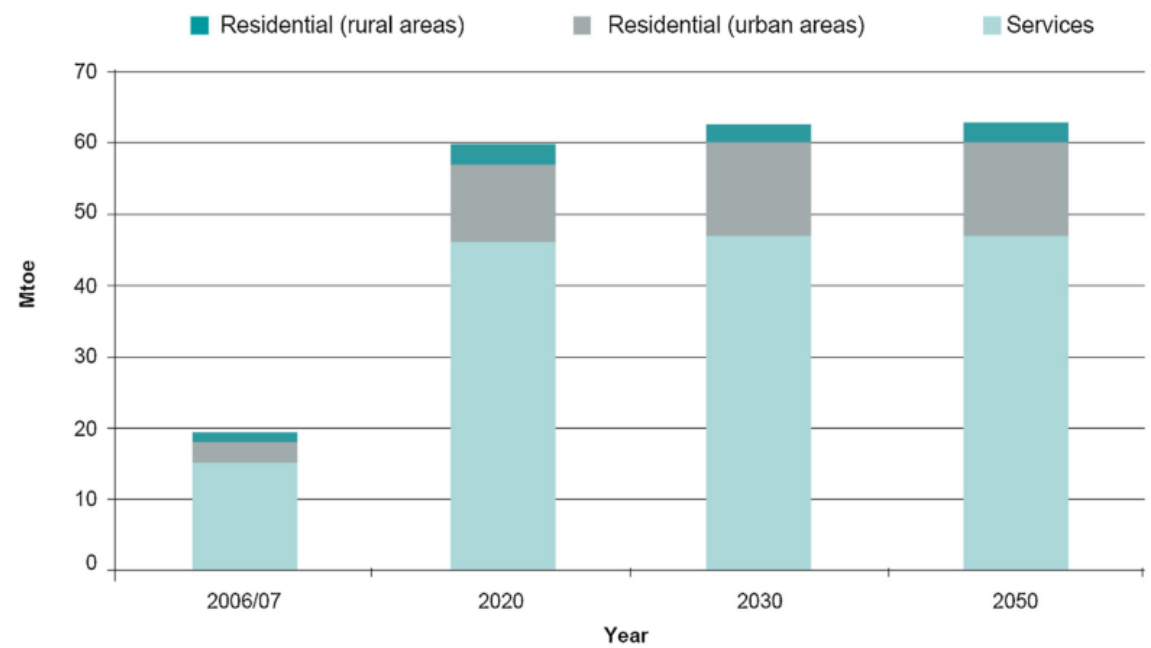

Fig. 4. Illustration of cooling demand and projection in EU for residential and service delivery sectors. Adapted from Souayfane, et al. [6]

In light of the above, the sustainability of PCMs in building may be under serious test in view of increasing world population and emerging housing explosion. Since the thermal load in building is predicted to rise as a result of activities like heating and air conditioning, it may be of interest to study materials of comparable low thermal conductivity like fly-ash geopolymer materials as compliment for passive cooling in building for sustainable comfort.

\section{PROSPECT OF FLY-ASH GEOPOLYMER MATERIALS AS PASSIVE COOLING MATERIALS}

The possibilities of adopting fly-ash geoplymer materials for passive cooling in buildings with the incorporation of PCMs has received significant attention in some literatures but a lot of gap still exist on the concept of evaporative cooling and absorption using geopolymer materials as additives. According to Emdadi, et al. [20], a lot of low thermal conductivity materials have been extensively studied for this specific application, in which ceramic seems to be a good candidate for potential evaporative cooling application
[21]. Part of the conclusion drawn from laboratory analysis of most ceramics, as reported by Costelloe and Finn [22], showed that most porous ceramics demonstrate good mechanical characteristics, sustained chemical and abrasion resistance and most importantly, they are thermally stable. Key to the driving factors in cooling system is principally controlled by variables, such as: porosity of passive materials, configuration and composition of materials and the humidity of the environment [23]. In most cooling structures, several authors [24, 25] have confirmed that a high porosity evaporator, sometimes results in most cooling, while the low-porosity materials may result in virtually negligible levels of cooling. This assertion is evident in the result presented by Okada, et al. [26], where lotus ceramic demonstrated to be cooler, as a result of its heightened capillary rise level (of about $1300 \mathrm{~mm}$ ) above the convectional porous ceramics. The principle evaporative cooling is demonstrated in Figure 4, in which the passive evaporative cooling wall (PECW) is located in a shaded area that is free from both direct and solar influence, while its surface area can therefore be cooled via evaporation.

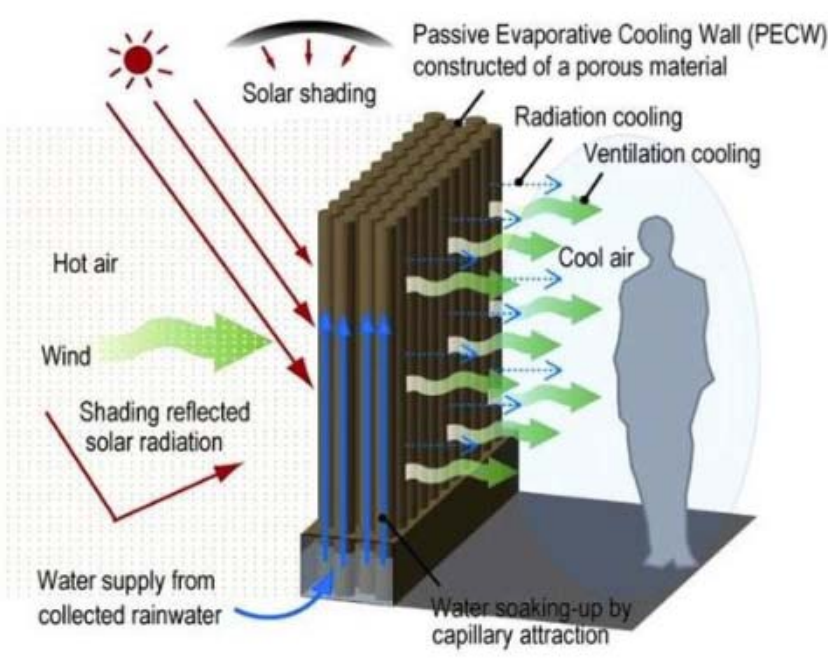

Fig. 5. Diagrammatic description of a passive cooling wall constructed with porous material with high tendency for water soaking-up ability. Adapted from Emdadi, et al. [20] 
The application of geopolymer materials for these specific purposes may not be necessarily far-fetched, going by its purported potentials. Several studies embarked upon by these authors [27, 28], have proved beyond any reasonable doubt that fly-ash geopolymer materials have good prospect at low temperature $(<100$ ${ }^{\circ} \mathrm{C}$ ) condition and their production technique releases six times less $\mathrm{CO}_{2}$ when compared to other additives in cement production. Of critical consideration in this research is that geopolymer materials seem to have derived its composition from by-products and fly-ash, which is to a larger extent, is more environmentallyfriendly when compared to other porous ceramics. This salient property may give further consideration for geopolymer materials to be considered as passive cooling materials and the authors suggest further experimental analysis to validate these potentials.

\section{AREAS FOR FURTHER RESEARCH}

From the concept of evaporative cooling and absorbtion technique, it can be found that there is a broad potential for future studies in these techniques particularly the integration of geopolymer materials for cooling purposes. Based on the shortcoming of PCMs under this context, a brief list of potential future research is offered for further experimental validation.

* Cost and economic evaluations of PCMs seem not to have been thoroughly addressed in many studies as it relates its application in building. Even though significant progresses have been recorded as per high capability of PCMs in sustaining comfort in building, only handful of these journals considered the economic sustainability. The construction industry must be convinced of their financial return of the initial investment to improve its patronage.

* As reported earlier, passive cooling techniques alone may not be adequate to reduce high energy demand in building as daily peak of surface temperature is dependent on climatic conditions among other factors. Therefore, a combination with geopolymer materials could be a potentially novel topic for future studies.

\section{CONCLUSIONS}

Going by the prospect of geopolymers materials as enunciated in the body of this work, it can therefore be inferred that this material remains a potential candidate for evaporative cooling system application. Key of the reason adduced to this fact, is that its manufacturing approach is more environmentally-friendly and in most cases, low firing temperatures are needed. In view of the fact that fly ash-based geopolymer materials are primary raw materials for the production of geopolymer materials, renders this research topic a promising and novel area that should be further explored. This development could serve as a way of addressing some of the environmental and energy issues that are currently bedevilling developing countries, via the reduction of waste volume of fly-ash and most importantly, reducing the global $\mathrm{CO}_{2}$ emissions. Meanwhile, lot of researches are still needed to validate the potential of introducing industrial and agricultural waste materials into fly-ash geopolymer for passive cooling application.

\section{REFERENCES}

[1] J. Weber, S. Strączyńska, A. Kocowicz, M. Gilewska, A. Bogacz, M. Gwiżdż, et al., "Properties of soil materials derived from fly ash 11years after revegetation of post-mining excavation," Catena, vol. 133, pp. 250-254, 2015.

[2] J. Van Jaarsveld, J. Van Deventer, and G. Lukey, "The characterisation of source materials in fly ash-based geopolymers," Materials Letters, vol. 57, pp. 1272-1280, 2003.

[3] A. Bilodeau and V. M. Malhotra, "High-volume fly ash system: the concrete solution for sustainable development," in CANMET/ACI. Séminaire international, 2000.

[4] A. Yilmaz and N. Degirmenci, "Possibility of using waste tire rubber and fly ash with Portland cement as construction materials," Waste Management, vol. 29, pp. 1541-1546, 2009.

[5] Z. Zhang, J. L. Provis, A. Reid, and H. Wang, "Mechanical, thermal insulation, thermal resistance and acoustic absorption properties of geopolymer foam concrete," Cement and Concrete Composites, vol. 62, pp. 97-105, 2015.

[6] F. Souayfane, F. Fardoun, and P.-H. Biwole, "Phase change materials (PCM) for cooling applications in buildings: A review," Energy and Buildings, vol. 129, pp. 396-431, 2016.

[7] N. Zhu, Z. Ma, and S. Wang, "Dynamic characteristics and energy performance of buildings using phase change materials: a review," Energy Conversion and Management, vol. 50, pp. 3169-3181, 2009.

[8] C. Chen, H. Guo, Y. Liu, H. Yue, and C. Wang, "A new kind of phase change material (PCM) for energy-storing wallboard," Energy and Buildings, vol. 40, pp. 882-890, 2008.

[9] Y. Konuklu, M. Ostry, H. O. Paksoy, and P. Charvat, "Review on using microencapsulated phase change materials (PCM) in building applications," Energy and Buildings, vol. 106, pp. $134-155,2015$

[10] H. Akeiber, P. Nejat, M. Z. A. Majid, M. A. Wahid, F. Jomehzadeh, I. Zeynali Famileh, et al., "A review on phase change material (PCM) for sustainable passive cooling in building envelopes," Renewable and Sustainable Energy Reviews, vol. 60, pp. 1470-1497, 2016.

[11] E. ul Haq, S. Kunjalukkal Padmanabhan, and A. Licciulli, "Synthesis and characteristics of fly ash and bottom ash based geopolymers-A comparative study," Ceramics International, vol. 40, pp. $2965-$ 2971, 2014.

[12] O. Adekomaya, T. Jamiru, R. Sadiku, and Z. Huan, "Minimizing energy consumption in refrigerated vehicles through alternative external wall," Renewable and Sustainable Energy Reviews, vol. 67, pp. 89-93, 2017.

[13] P. Duxson, J. L. Provis, G. C. Lukey, S. W. Mallicoat, W. M. Kriven, and J. S. Van Deventer, 
"Understanding the relationship between geopolymer composition, microstructure and mechanical properties," Colloids and Surfaces A: Physicochemical and Engineering Aspects, vol. 269, pp. 47-58, 2005.

[14] H.-C. Wu and P. Sun, "New building materials from fly ash-based lightweight inorganic polymer," Construction and Building Materials, vol. 21, pp. 211-217, 2007.

[15] Y. Qin, "A review on the development of cool pavements to mitigate urban heat island effect," Renewable and Sustainable Energy Reviews, vol. 52, pp. 445-459, 2015.

[16] Z. Zhang and X. Fang, "Study on paraffin/expanded graphite composite phase change thermal energy storage material," Energy Conversion and Management, vol. 47, pp. 303310, 2006.

[17] S. Hasnain, "Review on sustainable thermal energy storage technologies, Part I: heat storage materials and techniques," Energy Conversion and Management, vol. 39, pp. 1127-1138, 1998.

[18] G. A. Blengini and T. Di Carlo, "The changing role of life cycle phases, subsystems and materials in the LCA of low energy buildings," Energy and Buildings, vol. 42, pp. 869-880, 2010.

[19] L. F. Cabeza, A. Castell, C. Barreneche, A. De Gracia, and A. Fernández, "Materials used as PCM in thermal energy storage in buildings: a review," Renewable and Sustainable Energy Reviews, vol. 15, pp. 1675-1695, 2011.

[20] Z. Emdadi, N. Asim, M. A. Yarmo, and R. Shamsudin, "Investigation of More Environmental Friendly Materials for Passive Cooling Application Based on Geopolymer," APCBEE Procedia, vol. 10, pp. 69-73, 2014.

[21] E. Ibrahim, L. Shao, and S. B. Riffat, "Performance of porous ceramic evaporators for building cooling application," Energy and Buildings, vol. 35, pp. 941-949, 2003.

[22] B. Costelloe and D. Finn, "Thermal effectiveness characteristics of low approach indirect evaporative cooling systems in buildings," Energy and Buildings, vol. 39, pp. 1235-1243, 2007.

[23] V. Fabi, R. V. Andersen, S. Corgnati, and B. W. Olesen, "Occupants' window opening behaviour: A literature review of factors influencing occupant behaviour and models," Building and Environment, vol. 58, pp. 188-198, 2012.

[24] S. Wei, R. Jones, and P. de Wilde, "Driving factors for occupant-controlled space heating in residential buildings," Energy and Buildings, vol. 70, pp. 3644, 2014.
[25] K. Fong, T. T. Chow, C. K. Lee, Z. Lin, and L. Chan, "Comparative study of different solar cooling systems for buildings in subtropical city," Solar Energy, vol. 84, pp. 227-244, 2010.

[26] K. Okada, S. Uchiyama, T. Isobe, Y. Kameshima, A. Nakajima, and T. Kurata, "Capillary rise properties of porous mullite ceramics prepared by an extrusion method using organic fibers as the pore former," Journal of the European Ceramic Society, vol. 29, pp. 2491-2497, 2009.

[27] S. Wang and $\mathrm{H}$. Wu, "Environmental-benign utilisation of fly ash as low-cost adsorbents," Journal of hazardous materials, vol. 136, pp. 482501, 2006.

[28] E. Diaz, E. Allouche, and S. Eklund, "Factors affecting the suitability of fly ash as source material for geopolymers," Fuel, vol. 89, pp. 992996, 2010.

\section{ACKNOWLEDGEMENTS}

The authors would like to thank some of the literatures whose contents have helped to establish the prospect of geopolymer as a candidate for passive cooling materials. Although, the usual disclaimer applies, the views expressed in this study are primarily the opinion of the authors.

Authors: Oludaisi Adekomaya, Olabisi Onabanjo University, Agricultural and Mechanical Engineering, Faculty of Engineering, College of Engineering and Environmental Studies, Nigeria

Oludaisi Adekomaya, Tamba Jamiru, Zhongjie Huan, Department of Mechanical Engineering, Mechatronics and Industrial Design, Faculty of Engineering and Built Environment, Tshwane University of Technology, Pretoria 0001, South Africa.

Rotimi Sadiku, Department of Chemical and Metallurgical Engineering, Faculty of Engineering and Built Environment, Tshwane University of Technology, Pretoria 0001, South Africa.

Bilianu Oboirien, Council for Scientific and Industrial Research (CSIR), Pretoria South Africa.

E-mail:

(Corresponding author: oludaisiyetunde@gmail.com, adekomaya.oludaisi@oouagoiwoye.edu.ng, adekomayao@tut.ac.za) 